\title{
Mixtures of SCFA, composed according to physiologically available concentrations in the gut lumen, modulate histone acetylation in human HT29 colon cancer cells
}

\author{
Jeannette Kiefer, Gabriele Beyer-Sehlmeyer and Beatrice L. Pool-Zobel* \\ Department of Nutritional Toxicology, Institute for Nutrition, Friedrich-Schiller-University, Dornburger Str. 25, D-07743 Jena, \\ Germany
}

(Received 22 March 2006 - Revised 25 July 2006 - Accepted 3 August 2006)

\begin{abstract}
Intake of fibre has beneficial properties on gut health. Butyrate, a product of bacterial gut fermentation, is thought to contribute to positive effects by retarding growth and enhancing apoptosis of tumour cells. One mechanism is seen in its capacity to modulate histone acetylation and thereby transcriptional activity of genes. Next to butyrate, propionate and acetate are also major products of gut fermentation and together they may exert different potencies of cellular effects than butyrate alone. Since virtually nothing is known on combination effects by SCFA mixtures, here we had the aim to assess how physiological relevant concentrations and mixtures of SCFA modulate histone acetylation in human colon cells. HT29 colon cancer cells were incubated with mixtures of butyrate, acetate and propionate and with the individual compounds as controls. Histone acetylation was determined with acid-urea gel electrophoresis and immunoblotting. Acetylated histones slowly increased over $24 \mathrm{~h}$ and persisted up to $72 \mathrm{~h}$ in butyrate-treated HT29 cells. Butyrate $(5-40 \mathrm{mM})$ and propionate $(20-40 \mathrm{~mm})$ enhanced histone acetylation significantly after $24 \mathrm{~h}$ incubation, whereas acetate $(2.5-80 \mathrm{mM})$ was ineffective. Mixtures of these SCFA also modulated histone acetylation, mainly due to additive effects of butyrate and propionate, but not due to acetate. In conclusion, physiological concentrations of propionate together with butyrate could have more profound biological activities than generally assumed. Together, these SCFA could possibly mediate important processes related to an altered transcriptional gene activation and thus contribute to biological effects possibly related to cancer progression or prevention.
\end{abstract}

SCFA: Histone acetylation: Colon tumour cells

Epidemiological studies support colon cancer-preventing activities of fruits, legumes and cereals containing fibre (Peters et al. 2003; Bingham et al. 2005). It has been implied that SCFA, produced in the gut lumen as a consequence of microbial fibre fermentation, are important in relation to fibre intake and colon cancer prevention (McIntyre et al. 1993). SCFA, and butyrate in particular, are energy sources for the colonic mucosal enterocytes. Moreover, butyrate seems to be of essential importance for the metabolic welfare of normal intestinal epithelia where it prevents apoptosis and subsequent mucosal atrophy (Wächterhäuser \& Stein, 2000; Klampfer et al. 2003). Opposed to this, in colon carcinoma cells butyrate inhibits proliferation, causes differentiation and induces apoptosis at low concentrations (Barnard \& Warwick, 1993; Scheppach, 1994; Hague \& Paraskeva, 1995). Additionally, butyrate protects human colon cells from DNA damage (Abrahamse et al. 1999; Ebert et al. 2001) and induces members of the glutathione S-transferase biotransformation genes (Ebert et al. 2003; Pool-Zobel et al. 2005). An important mechanism by which butyrate causes biological effects in colon carcinoma cells has been proposed to be the hyperacetylation of $\mathrm{H} 3$ and $\mathrm{H} 4$ core histones by inhibiting histone deacetylases (HDAC) (Hinnebusch et al. 2002).
Histone acetylation influences transcription by loosening histone-DNA contacts, thus making the DNA accessible for transcription factors. Imbalance in histone acetylation can lead to transcriptional dysregulation and silencing of genes that are involved in control of cell-cycle progression, differentiation, apoptosis and cancer development (Marks et al. 2001). For instance, butyrate may mediate the reactivation of cell cycle arrest caused by the silenced gene $\mathrm{p} 21^{\mathrm{WAF} 1 / \mathrm{CIP} 1}$ by acetylation of histones in its gene promoter (Archer et al. 1998; Sambucetti et al. 1999). Additional genes, also critical for cancer progression, were identified as inducible by histone acetylation of the promotor region (Iacomino et al. 2001; Ragione et al. 2001). The main SCFA, acetate and propionate, which also occur in the gut, have not been well investigated. Also, to our knowledge there are no reports available on the effects on histone acetylation of mixtures of SCFA, as they are formed in the gut lumen.

In contrast, the effects of butyrate are well characterized. A recent study on HT29 has shown that butyrate most effectively $(2 \cdot 2$-fold $)$ induced total histone acetylation at a concentration of $5 \mathrm{~mm}$, followed by valerate $(5 \mathrm{~mm})(1 \cdot 6$-fold $)$ and propionate $(5 \mathrm{~mm})$ (1.4-fold). Acetate $(5 \mathrm{~mm})$ did not enhance histone acetylation (Hinnebusch et al. 2002). Concentrations of $5 \mathrm{~mm}$ have 
been studied most frequently (Cousens et al. 1979; Siavoshian et al. 2000; Hinnebusch et al. 2002). In order to evaluate the biological impact of SCFA as found in the human gut, however, investigations of physiologically relevant concentrations are important. The three main SCFA, butyrate, propionate and acetate, can be found in the gut in considerably higher mM concentrations. Therefore, effects of SCFA on histone acetylation should be explored using the amounts expected to occur in the human gut lumen after ingestion of dietary fibre. These concentrations are $40-80 \mathrm{~mm}, 10-25 \mathrm{~mm}$ and $10-20 \mathrm{~mm}$ for acetate, propionate and butyrate, respectively (Schröder \& Stein, 1997; Alles et al. 1999; Jenkins et al. 1999; Topping \& Clifton, 2001). The relative molar proportions range from $50-65 \%$ for acetate, from $10-25 \%$ for propionate and from $10-25 \%$ for butyrate, depending on the fibre consumed (Schröder \& Stein, 1997; Alles et al. 1999; Jenkins et al. 1999; Topping \& Clifton, 2001).

The present study had the aim of investigating mixtures of SCFA, in concentrations as they occur in the gut lumen, on histone H4 acetylation in human colon cancer cells HT29. We also investigated the effects of the compounds individually, namely, acetate $(2.5-80 \mathrm{~mm})$, propionate $(2.5-40 \mathrm{mM})$, butyrate $(2 \cdot 5-40 \mathrm{~mm})$. The concentration ranges were larger than had been investigated before. The mixtures were composed at molar ratios of $69: 16: 15,75: 11: 14$ and $43: 24: 33$ for acetate, propionate and butyrate, respectively. The compositions of these mixtures were based on the molar ratios found in in vitro fermentation samples obtained with human slurries and dietary fibre sources (Beyer-Sehlmeyer et al. 2003). The last mentioned mixture, particularly, reflects the fermentation of dietary fibres that are more beneficial to gut health and integrity. A predominant property of putative beneficial mixtures is that they contain relatively high butyrate concentrations (Topping \& Clifton, 2001). Together, these studies were expected to provide novel information on whether the mixtures of SCFA were additive, inhibitory or even synergistic for modulating histone acetylation in comparison with each individual compound on its own.

\section{Materials and methods}

\section{Cell culture conditions}

The human colon carcinoma cell line HT29, established in 1964 (Fogh \& Trempe, 1975), was obtained from the
American Tissue Culture Collection (Rockville, MD, USA). The cells were maintained in Dulbecco's Modified Eagle Medium (Invitrogen, Karlsruhe, Germany) supplemented with $10 \%$ fetal calf serum (Invitrogen) and $1 \%$ penicillinstreptomycin (Life Technologies, Karlsruhe, Germany), grown in a humidified incubator $\left(5 \% \mathrm{CO}_{2} ; 95 \%\right.$ humidity; $\left.37^{\circ} \mathrm{C}\right)$ and harvested with trypsin-versene solution $(2.5 \%$; 1:5000; Invitrogen). Passages 26 to 53 were used for the experiments presented here. Viability was always over $85 \%$.

\section{Treatment of HT29 cells with SCFA and trichostatin A}

Stock solutions of Na-butyrate, Na-acetate (Merck, Darmstadt, Germany) and Na-propionate (Fisher Scientific $\mathrm{GmbH}$, Schwerte, Germany) (200 mm each) were prepared in Dulbecco's Modified Eagle Medium and frozen for storage until use $\left(-20^{\circ} \mathrm{C}\right)$. Similarly, SCFA mixtures were frozen as $50 \times$ stock solutions of the three main SCFA, acetate, propionate and butyrate. To yield appropriate concentrations in the cell culture medium, these mixtures were prepared as a $1 \times$ solution before each experiment. The ' $100 \%$ mixture' A contained $18.8 \mathrm{mM}-\mathrm{SCFA}$ at the ratio of $69: 16: 15$ (acetate:propionate: butyrate); mixture B contained $50.8 \mathrm{~mm}-\mathrm{SCFA}$ at the ratio of $75: 11: 14$; mixture $\mathrm{C}$ was composed of $52.4 \mathrm{mM}-\mathrm{SCFA}$ at the ratio of $43: 24: 33$ (see also Fig. 1). For assessing concentration-related effects of SCFA and mixtures, $3 \times 10^{6}$ cells were seeded for $24 \mathrm{~h}$ in six-well plates (Fisher Scientific $\mathrm{GmbH}$ ) and treated for an additional $24 \mathrm{~h}$ with butyrate $(2 \cdot 5-40 \mathrm{~mm})$, propionate $(2 \cdot 5-40 \mathrm{~mm})$, acetate $(2 \cdot 5-80 \mathrm{~mm})$ and SCFA mixtures A, B and C (100\% and at $10 \%$ dilutions) or medium alone (medium control). Trichostatin A (TSA; Sigma-Aldrich, Taufkirchen, Germany) was used as a positive control since it is an effective inducer of histone acetylation (Chen \& Townes, 2000). TSA was diluted in ethanol to yield a $3.3 \mathrm{~mm}$ stock solution and then stored frozen $\left(-20^{\circ} \mathrm{C}\right)$ until further use. For comparing kinetics of butyrate and TSA-mediated effects on histone acetylation, HT29 cells were grown in $75 \mathrm{ml}$ flasks (Fisher Scientific $\mathrm{GmbH}$ ) to $90-100 \%$ confluence within $5 \mathrm{~d}$. Butyrate $(5 \mathrm{~mm})$ or TSA $(3 \cdot 3 \mu \mathrm{M})$ were added for different time periods $(30 \mathrm{~min}-72 \mathrm{~h})$. In these experiments, medium with ethanol $(0.1 \%)$ served as the medium control. After incubation, both SCFA and TSA-treated cells were harvested and washed with PBS. The number of cells and cell viability
(A)

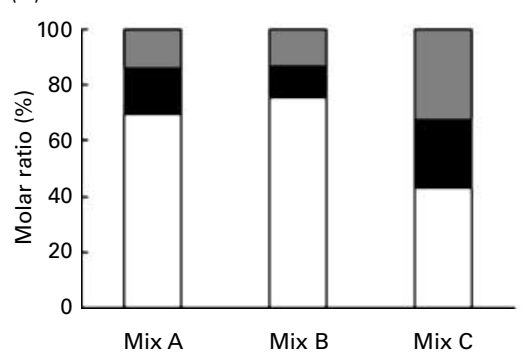

(B)

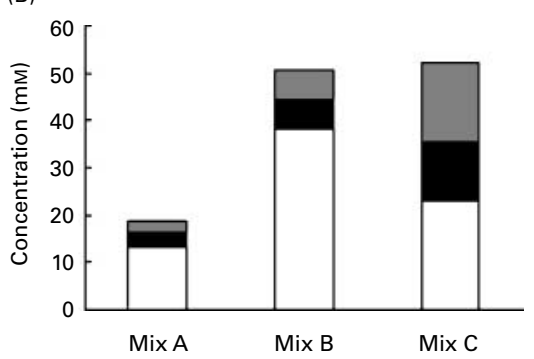

Fig. 1. Relative molar concentrations (A) and absolute concentrations (B) of acetate ( $\square$ ), propionate ( $\square$ ) and butyrate ( $\square$ ) in the mixtures A, B and C. The mixtures are composed to simulate SCFA pattern as obtained after fibre fermentation using human gut flora in vitro. Mixture A corresponds to a low fermentable fibre (watercress). Mixtures $\mathrm{B}$ and $\mathrm{C}$ are composed to simulate a high fermentable fibre with a lower and a high ratio of butyrate + propionate:acetate, as described for inulin and linseed flour (Beyer-Sehlmeyer et al. 2003). 
was determined. The suspension was centrifuged and the cell pellets were stored at $-20^{\circ} \mathrm{C}$ until histone extraction.

\section{Histone extraction}

Cell pellets (approximately $8 \times 10^{6}$ cells) were homogenized twice with a pellet-pistill (Fisher Scientific $\mathrm{GmbH}$ ) in $1 \mathrm{ml}$ lysis buffer $\left(1.2 \mathrm{~g} / \mathrm{l}\right.$ Tris; $5.2 \mathrm{~g} / \mathrm{ll}_{2} \mathrm{NO}_{4} ; 2 \mathrm{~g} / \mathrm{l} \quad \mathrm{MgCl}_{2}$ $\left(\times 6 \mathrm{H}_{2} \mathrm{O}\right) ; 86 \mathrm{~g} / \mathrm{l}$ sucrose; $0.24 \mathrm{~g} / 1$ pefabloc; $1 \%$ Triton-X$100(\mathrm{v} / \mathrm{v}) ; 1.54 \mathrm{~g} / \mathrm{l}$ dithiothreitol; $\mathrm{pH} 6.5)$ and the homogenate was centrifuged $\left(1000 \mathrm{~g} ; 10 \mathrm{~min}, 4^{\circ} \mathrm{C}\right)$. The supernatant fractions (cytosol) were discarded and the nuclear pellets were washed with PBS. Acid soluble proteins (histones) were extracted in $200 \mu \mathrm{l}$ extraction buffer $(3.46 \mathrm{~g} / \mathrm{l}$ Tris; $13.8 \mathrm{~g} / \mathrm{l}$ $\mathrm{Na}_{2}$ EDTA; $0.24 \mathrm{~g} / 1$ pefabloc; $1.54 \mathrm{~g} / \mathrm{l}$ dithiothreitol; $\mathrm{pH} 7.4$ ) with $1.1 \%(\mathrm{v} / \mathrm{v})$ concentrated $\mathrm{H}_{2} \mathrm{SO}_{4}$. After $2 \mathrm{~h}$ extraction, tubes were centrifuged $\left(11000 \mathrm{~g} ; 10 \mathrm{~min}, 4^{\circ} \mathrm{C}\right)$ and their supernatant fractions were precipitated with acetone overnight $\left(-20^{\circ} \mathrm{C}\right)$. On the next day, tubes were again centrifuged $\left(11000 \mathrm{~g}, 20 \mathrm{~min}, 4^{\circ} \mathrm{C}\right)$, supernatant fractions were discarded and the pellets containing the histones $(\mathrm{H} 1 ; \mathrm{H} 2 \mathrm{~A}$; H2B; H3; H4) were allowed to dry at room temperature (Cousens et al. 1979; Ajiro et al. 1981). Histones were diluted in distilled water and frozen at $-20^{\circ} \mathrm{C}$. Protein content was determined with an assay according to Bradford (1976) using bovine serum albumin as standard protein.

\section{Acid-urea gel electrophoresis}

The method of acid-urea gel electrophoresis is frequently used to determine total histone acetylation (O'Neil et al. 1999; Chen \& Townes, 2000; Pender et al. 2000). Acid-urea gel polymerization (20\% bis/acrylamide; $5 \%$ acetic acid; $0.36 \mathrm{~g} / \mathrm{l}$ urea; $20 \times 20 / 1.5 \mathrm{~mm}$ ) was performed overnight. Gels were then conditioned for approximately $2 \mathrm{~h}$ pre-electrophoresis (cathodic PAGE: $5 \%$ acetic acid; $400 \mathrm{~V} ; 13^{\circ} \mathrm{C}$ ) followed by a 1 -h run with scavenge buffer $(5 \%(\mathrm{v} / \mathrm{v})$ acetic acid; $0.36 \mathrm{~g} / \mathrm{ml}$ urea; $0.068 \mathrm{~g} / \mathrm{ml}$ mercaptoethylamine; $10 \%$ (v/v) glycerol; methyl green). Frozen histones were thawed and heated at $95^{\circ} \mathrm{C}$ for $5 \mathrm{~min}$. The volume with a total of $12 \mu \mathrm{g}$ histones (from approximately $1 \times 10^{6}$ cells) was diluted with the equal volume of $2 \times$ acid-urea-loading buffer $(5 \%(\mathrm{v} / \mathrm{v})$ acetic acid; $0.36 \mathrm{~g} / \mathrm{ml}$ urea; $20 \%$ (v/v) glycerol; $0.003 \mathrm{~g} / \mathrm{ml}$ dithiothreitol; methyl green). The samples were loaded onto the gel together with a standard solution composed of core histones (Upstate Biotechnology, New York, USA). Electrophoresis was performed with $5 \%(\mathrm{v} / \mathrm{v})$ acetic acid electrophoresis buffer at $400 \mathrm{~V}$ and $13^{\circ} \mathrm{C}$ for $24 \mathrm{~h}$. Then gels were washed with bidest and stained with Coomassie blue (Coomassie Brilliant Blue R-250; Sigma-Aldrich). Five bands representing the different histone $\mathrm{H} 4$ acetylation variants were analysed densitometrically using 'Fluor S Multi Imager' (BioRad, München, Germany). Data were expressed as the percentage of band signals for deacetylated $\left(\mathrm{H}_{4}\right)$ or acetylated (sum of $\mathrm{H}_{1}, \mathrm{H}_{4}$, $\left.\mathrm{H} 4_{3}, \mathrm{H} 4_{4}\right) \mathrm{H} 4$ variants compared with the sum of all five bands of histone $\mathrm{H} 4$ (whole H4) (optical density units (\%)). Non-detectable bands were set to equal zero. ( $\mathrm{H}_{1}$ 1-fold; $\mathrm{H} 4_{2}$ 2-fold; $\mathrm{H}_{3} 3$ 3-fold; $\mathrm{H}_{4} 4$-fold acetylated H4.)

\section{Histone immunoblotting}

Frozen histones were thawed and heated at $95^{\circ} \mathrm{C}$ for $5 \mathrm{~min}$. Histones $(12 \mu \mathrm{g})$ were diluted with the equal volume of $2 \times$ loading buffer $(0.03 \mathrm{~g} / \mathrm{ml}$ Tris; $4 \%(\mathrm{w} / \mathrm{v})$ SDS; $20 \%(\mathrm{v} / \mathrm{v})$ glycerol; $0.003 \mathrm{~g} / \mathrm{ml}$ dithiothreitol; bromphenolblue; $\mathrm{pH} 6 \cdot 8$ ). The mixture was loaded onto a $10 \times 10 \mathrm{~cm}$ bis/acrylamide gel $(5 \%$ stacking gel; $15 \%$ resolving gel) together with a molecular weight standard (low range; Biomol, Hamburg, Germany). After electrophoresis (120 V; $45 \mathrm{~min}$ ), the gel was blotted on a polyvinylidenefluoride (Schleicher \& Schuell, Dassel, Germany) membrane $\left(1 \mathrm{~mA} / \mathrm{cm}^{2} ; 2 \mathrm{~h}\right)$. The blot was blocked with $5 \%$ milk protein in Tris-buffered saline ( $0.1 \% \mathrm{v} / \mathrm{v}$ Tween, 20$)$ for $1 \mathrm{~h}$ and then incubated with the primary $\mathrm{H} 4$ antibody $(1: 1000$; $5 \%$ bovine serum albumin in Tris-buffered saline Tween) (Roche, Karlsruhe, Germany) overnight. Afterwards, blots were washed with Tris-buffered saline Tween, incubated with the secondary rabbit-alkaline phosphatase antibody (1:1000; $5 \%$ milk protein; Dako Deutschland $\mathrm{GmbH}$, Hamburg Germany), and chemifluorescence signals for whole H4 (as the control for equal sample loading) were determined using enhanced chemifluorescence as the substrate (Amersham, Freiburg, Germany). Optical density units (count $/ \mathrm{mm}^{2}$ ) were measured using a Fluor S Multi Imager (BioRad). For determining H4-acetylation, blots were stripped and all the afore-mentioned steps were repeated using the acetylated $\mathrm{H} 4$ antibody (Upstate Biotechnology). For comparing degrees of acetylation, the resulting fluorescence signal of acetylated H4 antibody was corrected for the signal of $\mathrm{H} 4$ antibody (internal control for equal sample loading) and normalized relative to the medium or $5 \mathrm{~mm}$ butyrate positive control (equal to 1).

\section{Statistical evaluation}

The GraphPad Prism software Version 4 (GraphPad Software Inc., San Diego, CA USA) was used to calculate a one-way ANOVA with Tukey's post test. Data of at least three experiments were evaluated to establish two-sided significance levels of independently reproduced determinations.

\section{Results}

Time response kinetics of butyrate on histone $H 4$ acetylation in HT29 cells

Before investigating the mixtures, first detailed studies on kinetics of butyrate-mediated effects were performed to establish assay conditions and to determine the sensitivity of the cell line. TSA, which is known for its pronounced histone acetylating activity (Chen \& Townes, 2000), was used as a positive control. Table 1 shows that butyrate mediated ( $5 \mathrm{~mm}$ ) histone acetylation increased slowly, as is apparent by the significant difference between deacetylated and acetylated $\mathrm{H} 4$, beginning at $4 \mathrm{~h}(P<0.01)$ up to $24 \mathrm{~h}(P<0.001)$. This plateau persisted for up to $72 \mathrm{~h}(P<0 \cdot 05)$. In contrast to butyrate, $3.3 \mu \mathrm{M}$-TSA immediately induced histone $\mathrm{H} 4$ acetylation as early as after $0.5 \mathrm{~h}$ incubation $(P<0.001)$, with a maximum induction after $4 \mathrm{~h}(P<0 \cdot 001)$. Subsequently, TSA acetylated histone H4 decreased to corresponding control levels after $24 \mathrm{~h}$. No effect was observed in the medium control. Based on these studies we performed our concentration finding studies for SCFA using treatment times up to $24 \mathrm{~h}$. 
Table 1. Kinetics of histone acetylation after treatment with butyrate and trichostatin A (TSA)†‡

(Mean values and standard deviations for three to four experiments)

\begin{tabular}{|c|c|c|c|c|c|}
\hline \multirow[b]{2}{*}{ Treatment } & \multirow{2}{*}{$\begin{array}{c}\text { Time } \\
\text { of incubation }\end{array}$} & \multicolumn{2}{|c|}{$\begin{array}{c}\text { Deacetylated } \\
\mathrm{H} 4\end{array}$} & \multicolumn{2}{|c|}{$\begin{array}{c}\text { Acetylated } \\
\text { H4 }\end{array}$} \\
\hline & & Mean & SD & Mean & SD \\
\hline \multirow[t]{6}{*}{ Medium control } & $30 \mathrm{~min}$ & $39 \cdot 0$ & $6 \cdot 6$ & $61 \cdot 0$ & $6 \cdot 6$ \\
\hline & $4 \mathrm{~h}$ & $43 \cdot 4$ & $7 \cdot 4$ & $56 \cdot 6$ & $7 \cdot 4$ \\
\hline & $6 \mathrm{~h}$ & $42 \cdot 3$ & $6 \cdot 2$ & $57 \cdot 7$ & $6 \cdot 2$ \\
\hline & $10 \mathrm{~h}$ & $39 \cdot 0$ & $7 \cdot 8$ & $61 \cdot 1$ & $7 \cdot 8$ \\
\hline & $24 \mathrm{~h}$ & $36 \cdot 9$ & $7 \cdot 7$ & $63 \cdot 1$ & $7 \cdot 7$ \\
\hline & $72 \mathrm{~h}$ & $42 \cdot 6$ & $5 \cdot 5$ & $57 \cdot 4$ & $5 \cdot 5$ \\
\hline \multirow[t]{6}{*}{ Butyrate $(5 \mathrm{~mm})$} & $30 \mathrm{~min}$ & 34.9 & $12 \cdot 6$ & $65 \cdot 1$ & $12 \cdot 6$ \\
\hline & $4 \mathrm{~h}$ & $29 \cdot 6$ & $13 \cdot 2$ & $70 \cdot 4^{\star \star}$ & $13 \cdot 2$ \\
\hline & $6 \mathrm{~h}$ & $28 \cdot 0$ & $14 \cdot 8$ & $72 \cdot 0^{* \star}$ & $14 \cdot 8$ \\
\hline & $10 \mathrm{~h}$ & $27 \cdot 3$ & $14 \cdot 2$ & $72 \cdot 8^{\star \star}$ & $14 \cdot 2$ \\
\hline & $24 \mathrm{~h}$ & $25 \cdot 7$ & $16 \cdot 9$ & $74 \cdot 3^{* * *}$ & $16 \cdot 9$ \\
\hline & $72 \mathrm{~h}$ & $27 \cdot 5$ & $6 \cdot 3$ & $72 \cdot 5^{\star}$ & $6 \cdot 3$ \\
\hline \multirow[t]{6}{*}{ TSA $(3.3 \mu \mathrm{m})$} & $30 \mathrm{~min}$ & $20 \cdot 1$ & $13 \cdot 6$ & $79 \cdot 9^{* \star *}$ & $13 \cdot 6$ \\
\hline & $4 \mathrm{~h}$ & $15 \cdot 7$ & $12 \cdot 4$ & $84 \cdot 3^{\star \star *}$ & $12 \cdot 4$ \\
\hline & $6 \mathrm{~h}$ & $21 \cdot 1$ & $18 \cdot 1$ & $79 \cdot 0^{* \star *}$ & $18 \cdot 1$ \\
\hline & $10 \mathrm{~h}$ & $28 \cdot 2$ & $17 \cdot 0$ & $71 \cdot 8^{\star \star *}$ & $17 \cdot 0$ \\
\hline & $24 \mathrm{~h}$ & $36 \cdot 0$ & $11 \cdot 1$ & $64 \cdot 0$ & $11 \cdot 1$ \\
\hline & $72 \mathrm{~h}$ & $44 \cdot 2$ & $7 \cdot 2$ & $55 \cdot 8$ & $7 \cdot 2$ \\
\hline
\end{tabular}

One-way ANOVA with Tukey's multiple comparison test were used to calculate the differences between the signals for acetylated histone $\mathrm{H} 4$ (sum of $\mathrm{H} 4_{1}, \mathrm{H} 4_{2}, \mathrm{H} 4_{3}$, $\mathrm{H} 44$ ) to deacetylated histone $\mathrm{H} 4(\mathrm{H} 40):{ }^{*} P<0.05 ;{ }^{* *} P<0.01 ;{ }^{* * *} P<0.001$.

$\dagger$ After acid-urea gel electrophoresis, gels were stained with Coomassie blue, and bands for $\mathrm{H} 4$ variants were analysed densitometrically.

‡For details of procedures, see p. 805 .

Concentration effect relationships of individual SCFA: butyrate

Fig. 2 shows a sample gel and the effects of 2.5-40 mM-butyrate on histone acetylation determined in three independently reproduced experiments. We found a concentration-related increase in band intensities of 1 - to 4-fold acetylated $\mathrm{H} 4$ variants $\left(\mathrm{H}_{4}, \mathrm{H}_{4}, \mathrm{H}_{4}, \mathrm{H}_{4}\right)$ and a decrease of deacetylated $\mathrm{H} 4$ $\left(\mathrm{H} 4_{0}\right)$ after $24 \mathrm{~h}$ treatment. Changes within histone $\mathrm{H} 4$ variants were characterized as a step-by-step modulation in the degree of acetylation. Compared with the medium control, the effects were significant after incubation with $10 \mathrm{~mm}(P<0.05), 20 \mathrm{~mm}$ $(P<0.01 ; P<0.05)$ and $40 \mathrm{~mm}(P<0.001)$ butyrate. Important changes were the decrease of the lowest band $\left(\mathrm{H}_{0}\right)$ with simultaneous increases of the third and fourth bands $\left(\mathrm{H} 4_{2}, \mathrm{H} 4_{3}\right)$. Results were confirmed using the specific method of immunoblotting, as shown in Fig. 3(A). Histone $\mathrm{H} 4$ acetylation was significantly induced at concentrations of $10 \mathrm{~mm}(P<0.01)$, $20 \mathrm{~mm}(P<0 \cdot 001)$ and $40 \mathrm{~mm}(P<0.001)$ butyrate. Additionally, there was a trend (not significant) for an increased yield of histone proteins after butyrate treatment (1.7-fold). Cell number was decreased to approximately $50 \%$ by 10-40 mM-butyrate treatment, however, without any effect on cell viability. Thus, histone acetylation was significantly modulated after $24 \mathrm{~h}$ treatment with butyrate at a concentration that resulted in a reduced cell number but not cell viability.

\section{Acetate and propionate}

We investigated acetate $(2 \cdot 5,5,20,40$ and $80 \mathrm{~mm})$ and propionate $(2.5,5,10,20$ and $40 \mathrm{~mm})$ at concentrations that resembled the physiologically available ranges that are expected to occur in the gut lumen after ingestion of dietary fibre. In these experiments, butyrate $(5 \mathrm{~mm})$ served as the positive control. In comparison with the medium control, no induction of histone acetylation was observed for acetate up to $80 \mathrm{~mm}$ (Fig. 3(B)). Propionate, however, significantly modulated histone acetylation at concentrations of $20 \mathrm{~mm}$ $(P<0.05)$ and $40 \mathrm{~mm}(P<0 \cdot 001)$ (Fig. 3(C)). To enable a better comparison of inducibility of histone acetylation

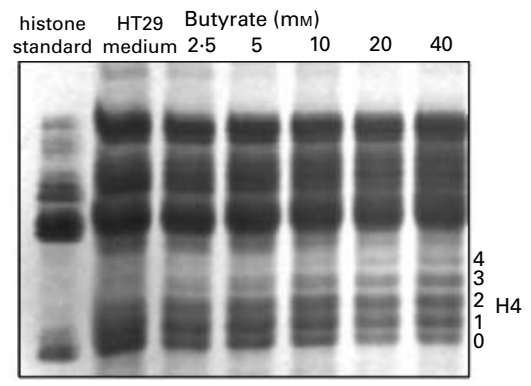

\begin{tabular}{|c|c|c|c|c|c|c|c|c|c|c|c|c|}
\hline \multirow{3}{*}{$\begin{array}{l}\text { Histone } \\
\text { acetylation }\end{array}$} & \multicolumn{12}{|c|}{ Butyrate treatment (mM) } \\
\hline & \multicolumn{2}{|l|}{0} & \multicolumn{2}{|c|}{2.5} & \multicolumn{2}{|l|}{5} & \multicolumn{2}{|l|}{10} & \multicolumn{2}{|l|}{20} & \multicolumn{2}{|l|}{40} \\
\hline & Mean & SD & Mean & SD & Mean & SD & Mean & SD & Mean & SD & Mean & SD \\
\hline $\begin{array}{l}\text { Deacetylated } \\
\mathrm{H} 4\left(\mathrm{H}_{0}\right)\end{array}$ & $42 \cdot 1$ & 1.7 & $35 \cdot 9$ & $3 \cdot 2$ & $34 \cdot 1$ & 2.5 & $31 \cdot 1^{*}$ & $3 \cdot 3$ & $24 \cdot 6^{\star *}$ & $5 \cdot 8$ & $16 \cdot 8^{* \star *}$ & $4 \cdot 7$ \\
\hline $\begin{array}{l}\text { Acetylated } \mathrm{H} 4 \\
\left(\mathrm{H} 4_{1+2+3+4}\right)\end{array}$ & 57.9 & 1.7 & $64 \cdot 1$ & $3 \cdot 2$ & 65.9 & 2.5 & 68.9 & $3 \cdot 3$ & $75 \cdot 4^{\star}$ & $5 \cdot 8$ & $83 \cdot 3^{* * *}$ & 4.7 \\
\hline
\end{tabular}

Fig. 2. Changes of deacetylated (0) and acetylated (1, 2, 3, and 4) histone $\mathrm{H} 4$ after $24 \mathrm{~h}$ treatment with butyrate. After acid-urea gel electrophoresis, gels were stained with Coomassie blue and bands for $\mathrm{H} 4$ variants were analysed densitometrically. Data were expressed as the percentage of band signals compared with the sum of all five bands for histone $\mathrm{H} 4$ (whole H4). One-way ANOVA with Tukey's multiple comparison test were used to calculate the differences between deacetylated $\left(\mathrm{H} 4_{0}\right)$ as well as acetylated histone $\mathrm{H} 4$ (sum of $\mathrm{H}_{1}, \mathrm{H} 4_{2}, \mathrm{H} 4_{3}, \mathrm{H} 4_{4}$ ) variants after treatment, to corresponding medium controls. Values are means and standard deviations for three independent experiments: $\left.{ }^{\star} P<0.05 ;{ }^{\star *} P<0.01 ;{ }^{\star \star \star} P<0.001\right)$. For details of procedures, see $p$. 805 . 


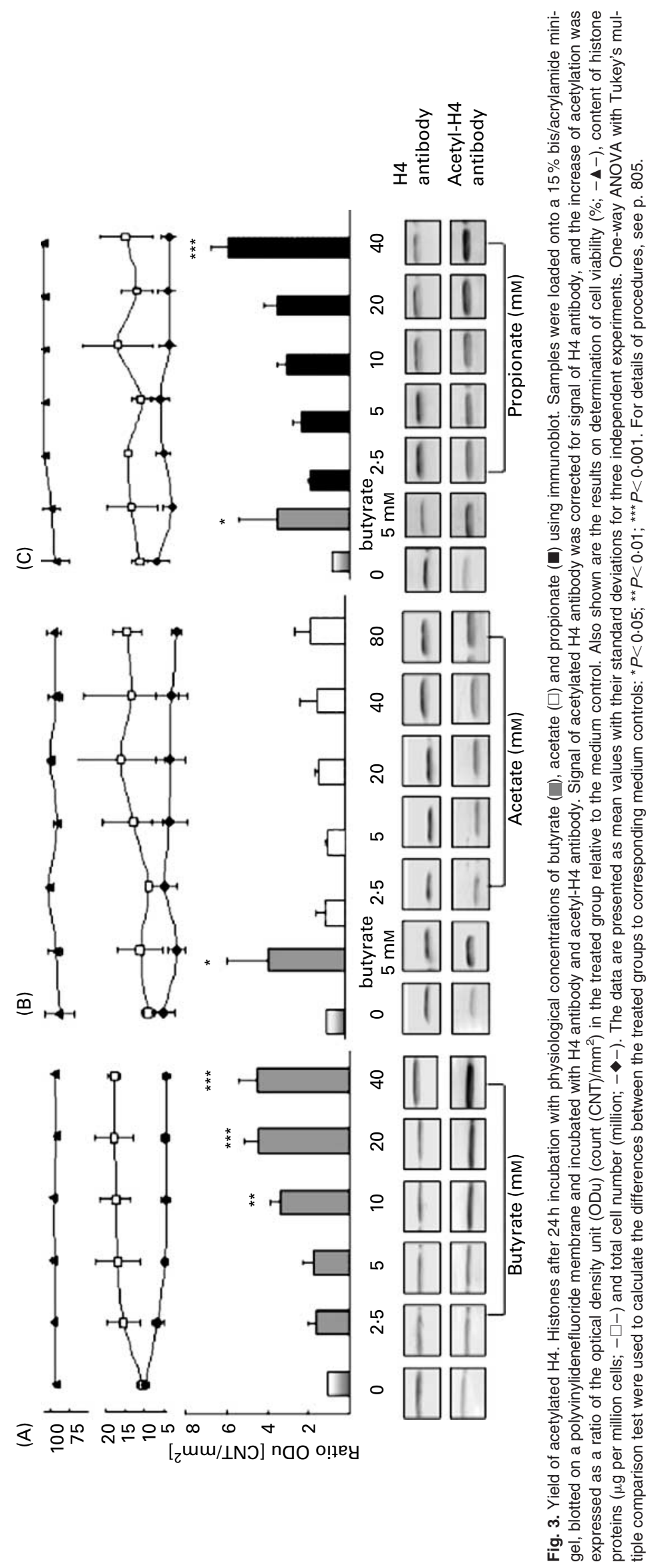


during different incubation conditions, we evaluated the relative acetylation levels by normalizing the values to the positive control (5 mM-butyrate). These analyses revealed that 10 and $20 \mathrm{~mm}$-propionate had approximately half of the acetylation-inducing capacity of butyrate, whereas $40 \mathrm{~mm}$-propionate was as effective as $40 \mathrm{~mm}$-butyrate (data not shown). At the highest SCFA concentrations, the cell numbers were decreased by approximately $40 \%$, without any effect on viability or histone-protein content.

\section{Effects of SCFA mixtures containing butyrate, propionate and acetate on histone acetylation}

Next we determined effects of mixtures of butyrate, propionate and acetate in various relative concentrations. The compositions of the $100 \%$ mixtures (and their 10\% dilutions) were based on the observed SCFA concentrations of various fermentation samples obtained from different fibre sources using human faecal slurries in vitro (Beyer-Sehlmeyer et al. 2003). They mimicked the relative concentrations probably occurring in the gut (Barry et al. 1995; Wächterhäuser \& Stein, 2000). Molar ratios of acetate, propionate and butyrate of mixtures $\mathrm{A}$ and $\mathrm{B}$ are comparable with each other $(69: 16: 15 v .75: 11: 14)$, but mixture A contained approximately only one-third of the total SCFA amounts used to prepare mixture B $(38.2,5.7$ and $6.9 \mathrm{~mm}$, respectively). Opposed to this, mixture $\mathrm{C}$ contained much higher propionate and butyrate amounts (12.6 and $17.2 \mathrm{mM}$, respectively) with a molar ratio of $43: 24: 33$. Its total SCFA concentration, however, was comparable to mixture B (Fig. 1). Again, butyrate $(5 \mathrm{~mm})$ was used as the positive control during these experiments. Fig. 4 shows that the different mixtures had different potencies of effectiveness. We normalized the results on the basis of the positive control (5 mM-butyrate), which was set to equal 1. Differences between medium and positive control were significant $(P<0 \cdot 001)$. Among the diluted mixtures at concentrations of $10 \%$, only mixture $\mathrm{C}$, which had the highest amount of butyrate and propionate (molar ratio of $43: 24: 33$ ), induced histone acetylation significantly $(P<0 \cdot 01)$. However, all three undiluted mixtures $(100 \%)$ induced histone acetylation $(P<0.05 ; P<0.001)$. Mixture A, at the $100 \%$ concentration, induced histone acetylation to the same extent, as the 5 mM-butyrate positive control (1.04- v. 1.00-fold). At this amount, mixture A contains only $2.8 \mathrm{~mm}$-butyrate, but $5.8 \mathrm{~mm}$-butyrate + propionate. Induction by mixture B (1.15fold) was less than by mixture C (2.53-fold). Again, not the total SCFA amounts $(50.8$ v. $52.4 \mathrm{mM})$, but rather more the sum of butyrate and propionate $(12.6 v .29 .8 \mathrm{~mm})$ seemed to be the important factor for induction of $\mathrm{H} 4$ histone acetylation. Results show also, when contained in mixtures of SCFA, butyrate was the most important factor for histone acetylation, followed by propionate, whereas acetate seemed to have no further effects. In addition, we found additive effects of butyrate and propionate reflecting the sum of their individual capacity to induce histone acetylation, but synergistic effects were not apparent.

\section{Discussion}

Acetylation of histones in the DNA of cancer cells has been associated with the reactivation or silencing of genes critical for cancer progression, differentiation and apoptosis (Sambucetti et al. 1999; Iacomino et al. 2001; Wu et al. 2001). The activation of genes by inhibiting histone deacetylators (HDAC) may be an important biological effect mediated by exogenous factors. Among different HDAC repressors, SCFA are of special interest since they occur naturally in the gut. The present study aimed to assess the importance of mixtures of SCFA for histone acetylation. For these studies we used concentrations as they are expected to occur in the gut lumen after ingestion of different dietary fibres.

Time response kinetics of histone acetylation by butyrate and TSA (a well-known HDAC-inhibitor) were compared in HT29 colon cancer cells that were treated for $0.5-72 \mathrm{~h}$.

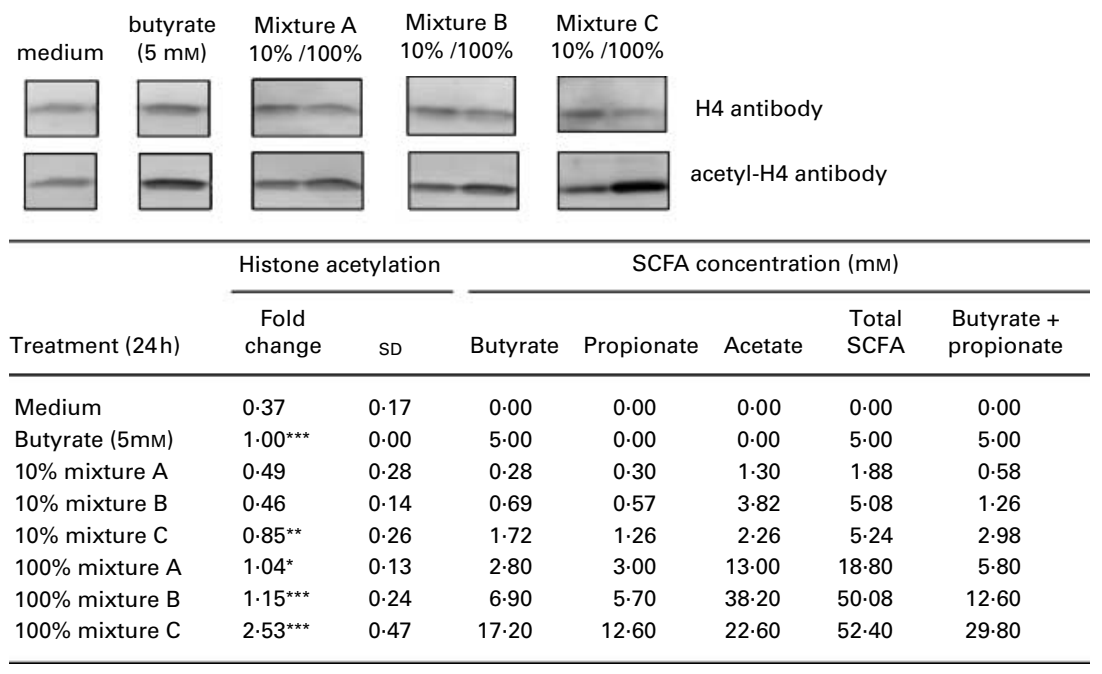

Fig. 4. Modulation of HT29 histone acetylation after incubation with different SCFA mixtures (10\% and $100 \%$ of physiologically available concentrations) and butyrate as a positive control by immunoblotting. Signals for acetylated $\mathrm{H} 4$ were corrected for whole $\mathrm{H} 4$ and compared with $5 \mathrm{~mm}$-butyrate. Mean values were significantly different from those for the other treatments (one-way ANOVA with Tukey's multiple comparison test): ${ }^{\star} P<0.05$; ${ }^{\star *} P<0.01$; ${ }^{\star \star \star} P<0.001$; different concentrations were separately analysed. Molar ratios of acetate:propionate:butyrate were: mixture $A=69: 16: 15 ;$ mixture $B=75: 11: 14$; mixture $\mathrm{C}=43: 24: 33$. For details of procedures, see p. 805 . 
The observed different effects of TSA and butyrate on histone acetylation were probably due to the shorter half life of TSA, as had been hypothesized earlier (Siavoshian et al. 2000). Removal of the HDAC-inhibitor, TSA, resulted in rapid deacetylation of histones within $4 \mathrm{~h}$ (Chen \& Townes, 2000). In contrast, the acetylation patterns by butyrate, as detected in the present study, may be a reflection of the kinetics of butyrate uptake by the cells, as we have reported earlier (Kautenburger et al. 2005). The studies have shown that approximately 15,40 and $60 \%$ of the applied butyrate $(2 \mathrm{mM})$ are consumed by HT29 cells after 24,48 and $72 \mathrm{~h}$ treatment, respectively. The resulting slow, but persistent, activation of histone acetylation by butyrate consequently may be important for the cancer-protecting activity of butyrate in the gut. Thus, Wu et al. (2001) have shown that prolonged histone hyperacetylation is required for induction of differentiation, apoptosis and growth factor unresponsiveness in HT29 cells. Therefore, a continuous and repetitive fibre intake may produce a prolonged histone hyperacetylation, which may be of physiological importance.

Next, concentration effect responses of SCFA (butyrate, propionate and acetate) on histone acetylation were assessed in the genome of colon cells. For these experiments concentrations were chosen that reached those that have been shown to occur under physiological relevant conditions after ingestion of different types of dietary fibre (Knudsen et al. 1997; Alles et al. 1999; Wächterhäuser \& Stein, 2000). This was a much larger SCFA concentration range than had been investigated before and resulted in an increase in histone acetylation at the higher butyrate and propionate concentrations. The effect was accompanied by growth suppression but not by a decreased viability of colon cells.

The major aim of the present study was to investigate the impact of SCFA as components of a mixture. These were made up to simulate the butyrate, propionate and acetate concentrations that had been analysed in various samples obtained by fermenting dietary fibre sources with human faecal slurries in vitro (Beyer-Sehlmeyer et al. 2003) and, therefore, possibly also occurring in the gut (Barry et al. 1995). Mixture A corresponds to fermentation of a low fermentable fibre such as that found in watercress (Beyer-Sehlmeyer et al. 2003). Mixture B resembled the relative SCFA contents after fermentation of inulin, kale or soya, whereas the composition of mixture $\mathrm{C}$ resembled the SCFA content after fermentation of linseed flour (Beyer-Sehlmeyer et al. 2003). Our previous studies on capacities of SCFA mixtures to modulate proliferation have shown additive effects of butyrate and propionate in suppressing HT29 growth (Beyer-Sehlmeyer et al. 2003). In the present study we show that there are also additive effects of propionate on induction of histone acetylation. It was recently reported that there are differences between the uptake of butyrate $(55 \% 2 \mathrm{~mm})$, acetate $(59 \% 6 \mathrm{~mm})$ and propionate $(33 \%$ $2 \mathrm{~mm}$ ) after $24 \mathrm{~h}$ incubation of intestinal epithelial goblet cells. This is connected to a repression of propionate uptake (down to $5 \%$ ) by the other components of the SCFA mixture (Gaudier et al. 2004). However, this property did not seem to play a role for modulation of histone acetylation in our experiments. The present results rather more support the hypothesis that the fibre fermentation product, propionate, has additive effects on butyrate and thus plays a much more important role for histone acetylation in the gut than was assumed previously. Moreover, whereas the majority of butyrate is used up by colonocytes as a source of energy, propionate could still be active when it reaches the liver, before it is further metabolized (Roberfroid, 2005).

The present results verify the importance of SCFA, in particular of butyrate and propionate, as inducers of histone acetylation, which is possibly associated with a modulated growth response of neoplastic or tumorigenic lesions in the gut. Propionate not only adds to butyrate's effect of suppressing growth, as shown previously, but also to butyrate's effect of modulating histone acetylation in human colon cells. Translated to the in vivo situation, the products of complex in vitro fibre fermentation, including butyrate and propionate, may contribute to suppressing agent activities in vivo resulting in the inhibition of tumour progression (Wattenberg, 1992; Johnson, 1995). It will be of interest in the future to determine effects on histone acetylation by additional fibre fermentation products, as they are formed in the gut. In light of the frequency of microneoplasia, which markedly increase with age (Heavey et al. 2004), the present findings are of relevance, since they possibly point to SCFA's potential to inhibit growth and survival of transformed colon cells and, thus, further progression. Now, it would be of interest to investigate in more depth how the observed effects by complex SCFA mixtures also affect gene expression and then to further identify involved genes.

\section{Acknowledgements}

This work was supported by the German Research Council, BMBF, Germany (FKZ.01EA0103), by ORAFTI, Tienen, Belgium (PRECANTOO) and a postgraduate scholarship of the Friedrich-Schiller-University within the budget of the Academy and Science Program of Thuringia (Germany).

\section{References}

Abrahamse SL, Pool-Zobel BL \& Rechkemmer G (1999) Potential of short chain fatty acids to modulate the induction of DNA damage and changes in the intracellular calcium concentration in isolated rat colon cells. Carcinogenesis 20, 629-634.

Ajiro K, Borun TW \& Cohen LH (1981) Phosphorylation states of different histone 1 subtypes and their relationship to chromatin functions during the HeLa S-3 cell cycle. Biochemistry 20, $1445-1454$.

Alles MS, Hartemink R, Meyboom S, Harryvan JL, Van Laere KMJ, Nagengast FM \& Hautvast JGAJ (1999) Effect of transgalactooligosaccharides on the composition of the human intestinal microflora and putative risk markers for colon cancer. Am J Clin Nutr 69, 980-991.

Archer SY, Meng S, Shei A \& Hodin RA (1998) p21WAF1 is required for butyrate-mediated growth inhibition of human colon cancer cells. Cell Biol 95, 6791-6796.

Barnard JA \& Warwick G (1993) Butyrate rapidly induces growth inhibition and differentiation in HT-29 cells. Cell Growth Differ 4, 495-501.

Barry J-L, Hoebler C, Macfarlane G, Macfarlane S, Mathers J, Reed K, Mortensen P, Nordgaard I, Rowland I \& Rumney C (1995) Estimation of the fermentability of dietary fibre in vitro: a European interlaboratory study. Br J Nutr 74, 303-322.

Beyer-Sehlmeyer G, Glei M, Hartmann E, Hughes R, Persin C, Böhm V, Rowland I, Schubert R, Jahreis G \& Pool-Zobel BL (2003) 
Butyrate is only one of several growth inhibitors produced during gut flora-mediated fermentation of dietary fibre sources. $\mathrm{Br} \mathrm{J} \mathrm{Nutr}$ 90, $1-15$.

Bingham SA, Norat T, Moskal A, et al. (2005) Is the association with fiber from foods in colorectal cancer confounded by folate intake? Cancer Epidemiol Biomarkers Prev 14, 1552-1556.

Bradford MM (1976) A rapid and sensitive method for the quantitation of microgram quantities of protein utilizing the principle of protein-dye binding. Anal Biochem 72, 248-254.

Chen WY \& Townes TM (2000) Molecular mechanism for silencing virally transducted genes involves histone deacetylation and chromatin condensation. Proc Natl Acad Sci USA 97, 377-382.

Cousens LS, Gallwitz D \& Alberts BM (1979) Different accessibilities in chromatin to histone acetylase. J Biol Chem 254, 1716-1723.

Ebert MN, Beyer-Sehlmeyer G, Liegiebel UM, Kautenburger T, Becker TW \& Pool-Zobel BL (2001) Butyrate induces glutathione S-transferases in human colon cells and protects from genetic damage by 4-hydroxy-2-nonenal. Nutr Cancer 41, 156-164.

Ebert MN, Klinder A, Peters WH, Schaferhenrich A, Sendt W, Scheele J \& Pool-Zobel BL (2003) Expression of glutathione S-transferases (GSTs) in human colon cells and inducibility of GSTM2 by butyrate. Carcinogenesis 24, 1637-1644.

Fogh J \& Trempe X (1975) Human tumor cells in vitro. In Human Tumor Cells In Vitro, pp. 115-159 [J Fogh, editor]. New York: Plenum Press.

Gaudier E, Jarry A, Blottière HM, de Coppet P, Buisine MP, Aubert JP, Laboisse C, Cherbut C \& Hoebler C (2004) Butyrate specifically modulates MUC gene expression in intestinal epithelial goblet cells deprived of glucose. Am J Physiol Gastrointest Liver Physiol 287, G1168-G1174.

Hague A \& Paraskeva C (1995) The short-chain fatty acid butyrate induces apoptosis in colorectal tumour cell lines. Eur J Cancer Prev 4, 359-364.

Heavey PM, McKenna D \& Rowland IR (2004) Colorectal cancer and the relationship between genes and the environment. Nutr Cancer 48, 124-141.

Hinnebusch BF, Meng S, Wu JT, Archer SY \& Hodin RA (2002) The effects of short-chain fatty acids on human colon cancer cell phenotype are associated with histone hyperacetylation. J Nutr 132, 1012-1017.

Iacomino G, Tecce MF, Grimaldi C, Tosto M \& Russo GL (2001) Transcriptional response of a human colon adenocarcinoma cell line to sodium butyrate. Biochem Biophys Res Commun 285, 1280-1289.

Jenkins DJA, Kendall CWC, Vuksan V, et al. (1999) The effect of wheat bran particle size on laxation and colonic fermentation. J Am Coll Nutr 18, 339-345.

Johnson IT (1995) Butyrate and markers of neoplastic change in the colon. Eur J Cancer Prev 4, 365-371.

Kautenburger T, Beyer-Sehlmeyer G, Festag G, et al. (2005) The gut fermentation product butyrate, a chemopreventive agent, suppresses glutathione S-transferase theta (hGSTT1) and cell growth more in human colon adenoma (LT97) than tumor (HT29) cells. $J$ Cancer Res Clin Oncol 131, 692-700.

Klampfer L, Huang J, Sasazuki T, Shirasawa S \& Augenlicht L (2003) Inhibition of interferon gamma signalling by the short chain fatty acid butyrate. Mol Canc Res 1, 855-862.
Knudsen BKE, Johansen HN \& Glitso V (1997) Rye dietary fiber and fermentation in the colon. Am Ass Cer Chem 42, 690-694.

McIntyre A, Gibson PR \& Young GP (1993) Butyrate production from dietary fibre and protection against large bowel cancer in a rat model. Gut 34, 386-391.

Marks PA, Rifkind RA, Richon VM, Breslow R, Miller T \& Kelly WK (2001) Histone deacetylases and cancer: causes and therapies. Nat Rev Cancer 1, 194-202.

O'Neil LP, Keohane AM, Lavender JS, McCrabe V, Heard E, Avner P, Brockdorff N \& Turner BM (1999) A developmental switch in $\mathrm{H} 4$ acetylation upstream of Xist plays a role in X chromosome inactivation. EMBO J 18, 2897-2907.

Pender SLF, Quinn JJ, Sanderson IR \& MacDonald T (2000) Butyrate upregulates stromelysin-1 production by intestinal mesenchymal cells. Am J Physiol Gastrointest Liver Physiol 279, G918-G924.

Peters U, Sinha R, Chatterjee N, et al. (2003) Dietary fibre and colorectal adenoma in a colorectal cancer early detection programme. Lancet 361, 1491-1495.

Pool-Zobel BL, Veeriah R, Sauer J, Kautenburger T, Kiefer J, Richter KK, Soom M \& Wölfl S (2005) Butyrate may enhance toxicological defence in primary, adenoma and tumor human colon cells by favourably modulating expression of glutathione S-transferases genes, an approach in nutrigenomics. Carcinogenesis 26, $1064-1076$.

Ragione FD, Criniti V, Della Pietra V, Borriello A, Oliva A, Indaco S, Yamamoto T \& Zappia V (2001) Genes modulated by histone acetylation as new effectors of butyrate activity. FEBS Lett $\mathbf{4 9 9}$, 199-204.

Roberfroid MB (2005) Inulin-Type Fructans. Functional Food Ingredients. Boca Raton, Florida: CRC Press.

Sambucetti LC, Fischer DD, Zabludoff S, Kwon PO, Chamberlin H, Trogani N, Xu H \& Cohen D (1999) Histone deacetylase inhibition selectively alters the activity and expression of cell cycle proteins leading to specific chromatin acetylation and antiproliferative effects. J Biol Chem 274, 34940-34947.

Scheppach W (1994) Effects of short chain fatty acids on gut morphology and function. Gut 35, S35-S38.

Schröder O \& Stein J (1997) Kurzkettige fettsäuren - physiologie und pathophysiologische implikationen (Short chain fatty acids - physiology and pathophysiologic implications). Akt Ernähr-Med 22, $86-96$.

Siavoshian S, Segain J-P, Kornprobst M, Cherbut C, Galmiche J-P \& Blottière HM (2000) Butyrate and trichostatin A effects on the proliferation/differentiation of human intestinal cells: induction of cyclin D3 and p21 expression. Gut 46, 507-514.

Topping DL \& Clifton PM (2001) Short-chain fatty acids and human colonic function: roles of resistant starch and nonstarch polysaccharides. Physiol Rev 81, 1031-1064.

Wächterhäuser A \& Stein J (2000) Rationale for the luminal provision of butyrate in intestinal deaseases. Eur J Nutr 39, 164-171.

Wattenberg LW (1992) Inhibition of carcinogenesis by minor dietary constituents. Cancer Res 52, 2085s-2091s.

Wu JT, Archer SY, Hinnebusch B, Meng S \& Hodin RA (2001) Transient vs. prolonged histone hyperacetylation: effects on colon cancer cell growth, differentiation, and apoptosis. Am J Physiol Gastrointest Liver Physiol 280, 482-490. 